\title{
Pengaruh Perceived Usefulness terhadap Mobile Users' Satisfaction dan Loyalty pada Aplikasi Go-Jek
}

Oleh:

Satya Rizky Irfansyah

Fakultas Ekonomi dan Bisnis Universitas Sebelas Maret

E-mail: satyariz15@gmail.com

Dosen Pembimbing:

Yusuf Muflikh Raharjo

\begin{abstract}
Perceived usefulness is a component found in every consumer in feeling usefulness in the products used. Previous literature studies have shown the importance of perceived usefulness in mobile app user loyalty. Perceived usefulness will affect the formation of mobile users' satisfaction which can lead to user loyalty Go-Jek application. This study aims to analyze the importance of perceived usefulness and responses in the form of satisfaction and loyalty in transportation marketing studies. In this study, using an online questionnaire to assess perceived usefulness, mobile users' satisfaction, and loyalty. Of the 220 online survey questionnaires given by respondents during the pandemic period in Indonesia, only 206 data fulfilled the criteria. Partial Least Square is used to test the proposed hypothesis. The results show that perceived usefulness positively and significantly affects mobile users' satisfaction and loyalty. The results also show the strong influence of perceived value on restaurant customer satisfaction. Taken together, the results of these studies provide additional and stronger empirical evidence for the perceived usefulness literature.
\end{abstract}

Keywords: perceived usefulness, mobile users' satisfaction, loyalty.

\section{Abstrak}

Perceived usefulness merupakan komponen yang terdapat pada setiap konsumen dalam merasakan kegunaan pada produk yang digunakan. Studi literatur sebelumnya telah menunjukkan pentingnya perceived usefulness pada loyalitas pengguna aplikasi ponsel. Perceived usefulness akan mempengaruhi pembentukan mobile users' satisfaction yang dapat menimbulkan loyalitas pengguna aplikasi Go-Jek. Penelitian ini bertujuan untuk menganalisis seberapa pentingnya perceived usefulness serta tanggapan berupa kepuasan dan loyalitas dalam studi pemasaran transportasi. Pada penelitian ini menggunakan kuesioner online untuk menilai perceived usefulness, mobile users' satisfaction, dan loyalitas. Dari 220 kuesioner survei online yang diberikan responden selama periode pandemi di Indonesia hanya 206 data yang memenuhi kriteria. Partial Least Square digunakan untuk menguji hipotesis yang diajukan. Hasilnya menunjukkan bahwa perceived usefulness secara positif dan signifikan mempengaruhi mobile users' satisfaction dan loyalitas. Hasilnya juga ditunjukkan pengaruh kuat nilai yang dirasakan pada kepuasan pelanggan restoran. Secara bersama-sama, hasil studi tersebut memberi bukti empiris tambahan dan lebih kuat untuk literatur perceived usefulness.

Keywords: perceived usefulness, mobile users' satisfaction, loyalty. 


\section{PENDAHULUAN}

Aplikasi mobil atau mobile application adalah program komputer yang dirancang untuk berjalan pada peranti bergerak seperti ponsel. Aplikasi mobil dapat membantu pengguna untuk lebih mudah mengakses layanan internet menggunakan perangkat mobile mereka (Wang et al., 2013). Inovasi teknologi tersebut telah bermunculan di beberapa sektor, salah satunya adalah bidang transportasi. Bukti inovasi dalam bidang bisnis transportasi adalah munculnya operator online ride-hailing dengan mentransformasi layanan ojek dan taksi secara online.

Aplikasi online ride-hailing terus bermunculan dan berkembang di seluruh dunia. Beberapa negara mengeluarkan aplikasi online ride-hailing untuk pemenuhan kebutuhan masyarakatnya. Berdasarkan data Top Ride-hailing and Taxi Apps Worldwide for July 2019 by Downloads, Uber merupakan aplikasi ride-hailing yang paling banyak diunduh di seluruh dunia untuk Juli 2019 dengan lebih dari 13 juta penginstalan, yang mewakili peningkatan 3 persen dari Juli 2018.

Layanan ride-haling mulai populer di Indonesia setelah kemunculan Uber di tahun 2014. Go-Jek dan Grab menyusul sebagai kompetiror layanan ride-hailing Uber di Indonesia. Pada awalnya, Gojek muncul sebagai layanan ojek online dan Grab dengan layanan taksi online. Meski pada awalnya Uber mengeluarkan layanan model Ride-Sharing, akhirnya perusahaan asal Amerika Serikat ini juga mengekor Grab dan Gojek sebagai layanan RideHailing. Pada akhirnya, Uber mulai menyerah yang mana saham dan aset Uber diambil alih oleh pesaingnya di pasar Asia Tenggara, termasuk Indonesia.

Go-Jek merupakan aplikasi layanan transportasi online yang memimpin di Indonesia. Perusahaan yang berdiri pada Februari 2011 ini berhasil menyelesaikan permasalahan transportasi ojek yang membuang waktu dengan mangkal di sebuah lokasi menjadi sebuah layanan transportasi eksklusif yang dapat dipesan melalui aplikasi dari smartphone sehingga lebih mudah dan menghemat waktu pelanggan maupun pengemudi. Pendiri Go-Jek telah memiliki pemahaman mengenai besarnya potensi bisnis pada sektor ini di era modern serta menangkap peluang dari besarnya penduduk Jakarta yang membutuhkan layanan transportasi yang cepat serta praktis. Menyatukan jasa ojek dan teknologi adalah solusi tepat bagi bisnis transportasi dan menjadi awal munculnya Go-Jek di Indonesia. Inovasi strategi yang dilakukan oleh Go-Jek selain berhasil menarik banyak sekali pengguna, juga berhasil merekrut ribuan pengemudi ojek dari berbagai kalangan, maupun juga dari pengemudi ojek konvensional seperti target dari pendiri GoJek sebelumnya.

Saat ini ada 21,7 juta orang di Indonesia yang menggunakan layanan ride-hailing atau berbagi tumpangan seperti Go-Jek. Hal ini berdasarkan laporan We Are Social 2020-Digital 
2020 Indonesia per Januari 2020. Laporan tersebut juga menunjukkan bahwa 75\% pengguna internet Indonesia menggunakan aplikasi mobile yang berhubungan dengan pemetaan. GoJek mengeluarkan berbagai macam layanan seperti GoFood, Gosend, GoMart, GoTix, GoPlay, dll. Layanan tersebut dapat meningkatkan keunggulan dan kegunaan yang dirasakan oleh pengguna aplikasi. Aplikasi Go-Jek tidak hanya beroperasional di Indonesia, namun juga beroperasi di beberapa negara di Asia Tenggara.

Loyalitas atau kesetian dipengaruhi oleh beberapa faktor, salah satunya adalah perceived usefulness. Calisir (2016) menyebutkan bahwa kegunaan yang diperoleh berpengaruh secara positif terhadap brand loyalty berdasarkan identifikasi konsumen dengan merek. Perceived usefulness atau yang biasanya disebut dengan kegunaan yang diperoleh adalah sejauh mana pengguna percaya bahwa menggunakan internet adalah alat yang berguna (Jeong \& Lambert, 2001). Adanya kegunaan yang dirasakan terhadap suatu produk atau perusahaan akan mengakibatkan konsumen selalu mengambil keputusan untuk menggunakan merek tersebut secara konsisten demi meningkatkan nilai positif diri terhadap publik atau masyarakat (Chebat et al., 2006). Terdapat faktor-faktor lain yang dapat dipengaruhi self-congruity seperti mobile users' satisfaction yang juga dapat mempengaruhi loyalitas.

Penelitian sebelumnya menjelaskan adanya korespondensi yang sangat penting antara perceived usefulness terhadap loyalitas (Tam, 2010). Loyalitas pengguna dari ridehailling Go-Jek dapat dihubungkan pada berbagai macam layanan yang ditawarkan (Fullerton, 2009). Loyalitas dan citra merek dapat terbentuk melalui dimensi toko (Jara dan Cliquet, 2012). Riset ini penting untuk dilakukan karena dapat mengetahui seberapa berpengaruh dampak dari perceived usefulness dalam memunculkan atau membentuk loyalitas dengan meliputi varibel lain seperti mobile users' satisfaction atau kepuasan pengguna aplikasi serta membahas tentang faktor mediasi. Penelitian ini dapat memberikan informasi terhadap pihak pemasar ride-hailling untuk memperbaiki atau meningkatkan strategi layanan pemasarannya. Sehingga, kedepannya ada kesadaran dari pihak perusahaan ridehailling dalam memperhatikan pelanggannya agar tetap loyal terhadap produk.

\section{TINJAUAN LITERATUR}

\section{Perceived Usefulness}

Perceived usefulness atau kegunaan yang dirasakan adalah sejauh mana pengguna percaya bahwa menggunakan internet adalah alat yang berguna (Jeong \& Lambert, 2001). $\mathrm{Hal}$ ini selanjutnya dicatat sebagai penggunaan teknologi yang meningkatkan kinerja konsumen (Davis, 1989). Kegunaan juga didefinisikan sebagai tingkat kepercayaan konsumen elektronik yang meningkatkan kinerja niat sebenarnya dalam hal membeli produk 
dari e-retailing (Davis, 1989). Kegunaan sendiri merupakan salah satu manfaat dari penggunaan internet sebagai sarana interaksi sehari-hari khususnya dalam perkembangan e-transformasi yang mana merupakan salah satu manfaat menggunakan internet. Pengguna internet memperoleh informasi yang lebih bermakna dan tidak terbatas untuk membuat keputusan pembelian yang lebih baik (Tam, 2010).

Calisir (2004) melakukan penelitian pada 51 pengguna akhir di 24 perusahaan yang disediakan oleh faktor vendor ERP. Penelitian tersebut terdapat pengaruh yang positif dan signifikan antara perceived usefulness dan loyalitas pengguna akhir dengan sistem ERP. Penelitian lain sebelumnya dilakukan oleh May-Chiun et al. (2014) pada 395 pengguna yang pernah melakukan transaksi elektronik dan pembelian elektronik setidaknya sekali dalam tiga bulan sebelumnya. Penelitian tersebut terdapat pengaruh yang positif dan signifikan antara perceived usefulness dan loyalitas pembeli elektronik. Oleh karena itu, dapat dihipotesiskan: $\mathrm{H}_{1}$ : Perceived Usefulness berpengaruh positif terhadap Loyalty

\section{Mobile Users' Satisfaction}

Mobile users' satisfaction atau kepuasan pengguna perangkat adalah penilaian pascapembelian konsumen dan tanggapan afektif terhadap total produk atau layanan yang dialami" (Lin dan Wang, 2006). Dalam studi ini, kepuasan didefinisikan sebagai pengalaman positif pengguna aplikasi layanan Go-Jek secara keseluruhan dari, dan perasaan terhadap, layanan aplikasi yang disediakan. Perusahaan harus meningkatkan kinerja keunggulan produk agar pelanggan merasakan kepuasan pada produk perusahaan (Türkyilmaz dan Özkan, 2007).

Amin et al. (2014) melakukan penelitian pada 302 pengguna ponsel di Malaysia. Penelitian tersebut terdapat pengaruh yang positif dan signifikan antara perceived usefulness dan kepuasan pengguna ponsel. Penelitian lain juga dilakukan Calisir (2004) pada 51 pengguna akhir di 24 perusahaan yang disediakan oleh faktor vendor ERP. Penelitian tersebut terdapat pengaruh yang positif dan signifikan antara perceived usefulness dan kepuasan pengguna dengan sistem ERP.

Oleh karena itu, dapat dihipotesiskan:

$\mathrm{H}_{2}$ : Perceived Usefulness berpengaruh positif terhadap Mobile users' satisfaction

\section{Loyalitas}

Loyalitas adalah merekomendasikan perusahaan kepada orang lain, mengatakan kata-kata positif (advokasi), melakukan pembelian berulang dan menganggap diri Anda sebagai pelanggan masa depan dari perusahaan tertentu (El-Nahas et al., 2013). Ketika pelanggan memiliki sikap positif terhadap perusahaan, dia akan membeli kembali produk 
perusahaan dan merekomendasikannya kepada orang lain (Akbar, 2009). Loyalitas pelanggan membantu perusahaan untuk mencapai keunggulan kompetitif di pasar dan dengan memiliki pelanggan setia perusahaan memiliki biaya yang lebih rendah, harga yang lebih tinggi dan keuntungan yang meningkat (Mokhtar, 2018).

Jungmin dan Minjung (2017) melakukan penelitian pada 303 wanita yang melakukan pembelian secara online dalam survei berbasis web di Korea Selatan. Penelitian tersebut terdapat pengaruh yang positif dan signifikan antara kepuasan pengguna aplikasi web dengan loyalitas pembeli toko online. Penelitian lain juga dilakukan oleh Hung et al. (2019) pada 400 wisatawan domestik yang mengunjungi Stasiun Kereta Tua Dongshin Taman Budaya Hakka, Taman Budaya Liudui Hakka, Taman Budaya Miaoli Hakka, dan Taman Budaya Pribumi Taiwan. Penelitian tersebut terdapat pengaruh yang positif dan signifikan antara kepuasan pengguna aplikasi web dengan loyalitas pengunjung.

Oleh karena itu, dapat dihipotesiskan:

$\mathrm{H}_{3}$ : Mobile users' satisfaction berpengaruh positif terhadap Loyalty

\section{METODE PENELITIAN}

\section{Sampel}

Responden penelitian ini adalah pengguna aplikasi Go-Jek yang sudah pernah menggunakan salah satu layanan di dalam Go-Jek (GoRide, GoFood, GoMart, GoSend, GoPlay, dll) yang memiliki usia minimal 17 tahun. Pengambilan sampel menggunakan teknik purposeful sampling. Untuk mengumpulkan data, kuesioner dibagikan dengan bantuan orangorang penting di banyak komunitas pengguna aplikasi Go-Jek.

Kuesioner online dibagikan kepada orang-orang yang memenuhi kriteria dari setiap komunitas pengguna aplikasi Go-Jek dengan menggunakan limersurvey. Dari 220 tanggapan diperoleh, terdapat 206 tanggapan diselesaikan dan memenuhi persyaratan penelitian ini. Data tersebut maka dilakukan pengolahan. Berikut ini adalah gambaran datanya.

Tabel 1. Pilihan Layanan Aplikasi Go-Jek

\begin{tabular}{|l|c|c|}
\hline \multicolumn{1}{|c|}{ Nama Layanan } & Total & Persentase \\
\hline GoCar / GoRide & 44 & $21.4 \%$ \\
\hline GoFood & 98 & $47.6 \%$ \\
\hline GoSend & 22 & $10.7 \%$ \\
\hline GoShop / GoMart & 18 & $8.7 \%$ \\
\hline GoPulsa & 16 & $7.8 \%$ \\
\hline
\end{tabular}




\begin{tabular}{|l|c|c|}
\hline GoPlay & 8 & $3.8 \%$ \\
\hline
\end{tabular}

Tabel 2. Waktu Penggunaan Layanan Aplikasi Go-Jek

\begin{tabular}{|l|c|c|}
\hline Waktu Penggunaan & Total & Persentase \\
\hline 1-2 kali & 55 & $26.6 \%$ \\
\hline 3-4 kali & 42 & $20.4 \%$ \\
\hline 5-6 kali & 68 & $33 \%$ \\
\hline Lebih dari 6 kali & 41 & $20 \%$ \\
\hline
\end{tabular}

Tabel 3. Rata-rata Pengeluaran Pengguna Layanan Aplikasi Go-Jek

\begin{tabular}{|l|c|c|}
\hline Pengeluaran & Total & Persentase \\
\hline Dibawah 150.000 & 63 & $30.6 \%$ \\
\hline $150.001-300.000$ & 80 & $38.8 \%$ \\
\hline $300.001-450.001$ & 30 & $14.5 \%$ \\
\hline $450.001-600.000$ & 24 & $11.7 \%$ \\
\hline Diatas 600.000 & 9 & $4.4 \%$ \\
\hline
\end{tabular}

Tabel 4. Kriteria Responden

\begin{tabular}{|l|l|c|c|}
\hline Kriteria & Deskripsi & Total & Persentase \\
\hline \multirow{4}{*}{ Jenis Kelamin } & Laki-Laki & 98 & $47.6 \%$ \\
\cline { 2 - 4 } & Perempuan & 108 & $52.4 \%$ \\
\hline \multirow{5}{*}{ Usia } & $17-25$ tahun & 145 & $70.4 \%$ \\
\cline { 2 - 4 } & $26-35$ tahun & 44 & $21.3 \%$ \\
\cline { 2 - 4 } & $36-45$ tahun & 14 & $6.8 \%$ \\
\cline { 2 - 4 } & $46-55$ tahun & 3 & $1.5 \%$ \\
\cline { 2 - 4 } & Dibawah Rp2.500.000 & 118 & $57.3 \%$ \\
\cline { 2 - 4 } & Rp2.500.001-Rp5.000.000 & 52 & $25.2 \%$ \\
\cline { 2 - 4 } & Rp5.000.001-Rp7.500.000 & 25 & $12.1 \%$ \\
\cline { 2 - 4 } & Rp7.500.001- Rp10.000.000 & 8 & $1.9 \%$ \\
\cline { 2 - 4 } & Diatas Rp10.000.000 & 3 & $18.9 \%$ \\
\hline Tingkat Pendidikan & SMA & 39 & $51.5 \%$ \\
\cline { 2 - 4 } & Diploma (D3) & 38 & \\
\cline { 2 - 4 } & Sarjana (S1) & & 106 \\
\hline
\end{tabular}




\begin{tabular}{|l|l|l|l|}
\hline & Magister (S2) & 23 & $11.2 \%$ \\
\hline
\end{tabular}

\section{Measures}

Penelitian ini menggunakan kuesioner laporan diri untuk mengukur variabel Perceived Usefulness, Mobile Users' Satisfaction, dan Loyalty. Skala Likert 5 Poin didistribusikan ("Sangat tidak setuju" sampai " Sangat setuju") secara online. Perceived Usefulness diukur menggunakan skala 3 item yang dikembangkan oleh Amin et al., (2014). Mobile Users' Satisfaction diukur menggunakan skala 4 item yang dikembangkan oleh Amin et al., (2014). Loyalty diukur dengan menggunakan 3 item yang dikembangkan oleh Parasumaran et al., (2005).

Tabel 5. Kuesioner Pernyataan Penelitian

\begin{tabular}{|c|c|c|}
\hline Variabel & Instrumen & Pernyataan \\
\hline \multirow{3}{*}{$\begin{array}{l}\text { Perceived Usefulness } \\
\text { (Amin et. al., 2014) }\end{array}$} & PU01 & $\begin{array}{l}\text { Go-Jek membuat pekerjaan dan hidup saya lebih } \\
\text { mudah. }\end{array}$ \\
\hline & PU02 & $\begin{array}{l}\text { Go-Jek memungkinkan saya memperoleh } \\
\text { kebutuhan saya dengan mudah. }\end{array}$ \\
\hline & PU03 & Secara keseluruhan, Go-Jek bermanfaat. \\
\hline \multirow{4}{*}{$\begin{array}{l}\text { Mobile Users' Satisfaction } \\
\text { (Amin et. al., 2014) }\end{array}$} & MUS01 & Saya puas dengan layanan aplikasi Go-Jek. \\
\hline & MUS02 & Go-Jek merupakan aplikasi yang berhasil. \\
\hline & MUS03 & Go-Jek telah memenuhi harapan saya. \\
\hline & MUS04 & $\begin{array}{l}\text { Secara keseluruhan, saya merasa senang dengan } \\
\text { pengalaman saya dalam menggunakan layanan } \\
\text { Go-Jek. }\end{array}$ \\
\hline \multirow{3}{*}{$\begin{array}{l}\text { Loyalty } \\
\text { (Parasumaran et al., 2005) }\end{array}$} & L01 & $\begin{array}{l}\text { Saya menganggap aplikasi Go-Jek sebagai } \\
\text { alternatif terbaik. }\end{array}$ \\
\hline & L02 & $\begin{array}{l}\text { Saya berniat untuk tetap menjadi pengguna Go-Jek } \\
\text { dalam waktu dekat. }\end{array}$ \\
\hline & L03 & $\begin{array}{l}\text { Saya akan merekomendasikan aplikasi Go-Jek } \\
\text { kepada teman dan kerabat saya. }\end{array}$ \\
\hline
\end{tabular}

\section{DATA ANALYSIS \& RESULT}

Hipotesis penelitian diuji dengan menggunakan Partial Least Square Structural Pemodelan Persamaan (PLS-SEM) dengan SmartPLS 3.3.2. PLS-SEM diterapkan karena itu dapat mengatasi sejumlah variabel dependen dan independen secara bersamaan (Hair et al., 
2013). Ada dua tahapan dalam membuat analisis PLS-SEM. Pertama, mengevaluasi pengukuran model melalui uji validitas dan reliabilitas konstruk. Kedua, mengevaluasi model struktural untuk memeriksa efek langsung dan tidak langsung dari yang dikembangkan model. Hasilnya ditampilkan di bawah.

\section{Measurement model}

Untuk mengevaluasi model pengukuran dilakukan uji validitas dan reliabilitas untuk setiap konstruksi. Untuk memvalidasi konstruk, validitas konvergen dan diskriminan dianalisis. Sebuah konstruk dianggap memiliki validitas konvergen jika faktor pembebanannya adalah lebih besar dari 0,5 (Hair et al., 2013). Selain itu, disarankan untuk memiliki rata-rata varians diekstraksi lebih besar dari 0,5 (Fornell \& Larcker, 1981).

Pada Tabel 6 menunjukkan bahwa skor faktor loading dan AVE dari semua konstruksi memenuhi kriteria yang direkomendasikan untuk ditampilkan validitas konvergen. Sedangkan validitas diskriminan dievaluasi berdasarkan Fornell dan Kriteria Larcker. Sebuah konstruk dianggap lulus uji validitas diskriminan jika berbentuk persegi root dari setiap AVE konstruk memiliki nilai yang lebih besar daripada korelasi dengan laten lainnya konstruksi.

Berdasarkan Tabel 6, semua konstruk memiliki validitas diskriminan karena akar kuadrat AVE setiap konstruk lebih besar nilainya daripada korelasi dengan konstruk laten lainnya. Cronbach Alpha dan composite reliability digunakan untuk menguji reliabilitas sebuah instrumen, dianggap reliabel jika skor di atas 0,70 .

Tabel 6. Measurement Model Results (Uji Validitas \& Reliabilitas)

\begin{tabular}{|c|c|c|c|c|c|}
\hline Construct & Item & $\begin{array}{l}\text { Factor } \\
\text { Loading }\end{array}$ & $\begin{array}{c}\text { Cronbach } \\
\text { Alpha }\end{array}$ & $\begin{array}{c}\text { Composite } \\
\text { Reliability }\end{array}$ & AVE \\
\hline \multirow{3}{*}{$\begin{array}{l}\text { Perceived } \\
\text { Usefulness }\end{array}$} & PU01 & 0.944 & \multirow{3}{*}{0.935} & \multirow{3}{*}{0.959} & \multirow{3}{*}{0.885} \\
\hline & PU02 & 0.961 & & & \\
\hline & PU03 & 0.918 & & & \\
\hline \multirow{4}{*}{$\begin{array}{l}\text { Mobile } \\
\text { Users' } \\
\text { Satisfaction }\end{array}$} & MUS01 & 0.946 & \multirow{4}{*}{0.944} & \multirow{4}{*}{0.960} & \multirow{4}{*}{0.856} \\
\hline & MUS02 & 0.908 & & & \\
\hline & MUS03 & 0.914 & & & \\
\hline & MUS04 & 0.932 & & & \\
\hline \multirow{3}{*}{ Loyalty } & L01 & 0.921 & \multirow{3}{*}{0.929} & \multirow{3}{*}{0.955} & \multirow{3}{*}{0.875} \\
\hline & L02 & 0.954 & & & \\
\hline & L03 & 0.931 & & & \\
\hline
\end{tabular}


Tabel 7. Fornell-Larcker Criterion

\begin{tabular}{lccc}
\hline & Loyalty & Mobile Users' Satisfaction & Perceived Usefulness \\
\hline Loyalty & $\mathbf{0 . 9 3 5}$ & & \\
Mobile Users' Satisfaction & 0.337 & $\mathbf{0 . 9 2 5}$ & \\
Perceived Usefulness & 0.182 & 0.335 & $\mathbf{0 . 9 4 1}$ \\
\hline
\end{tabular}

\section{Structural Model}

Setelah mengevaluasi model pengukuran, dilakukan analisis model struktural untuk menguji hipotesis yang diajukan. Analisis ini dilakukan dengan menguji hipotesis langsung dan efek tidak langsung. Berikut hasil analisis PLS-SEM:

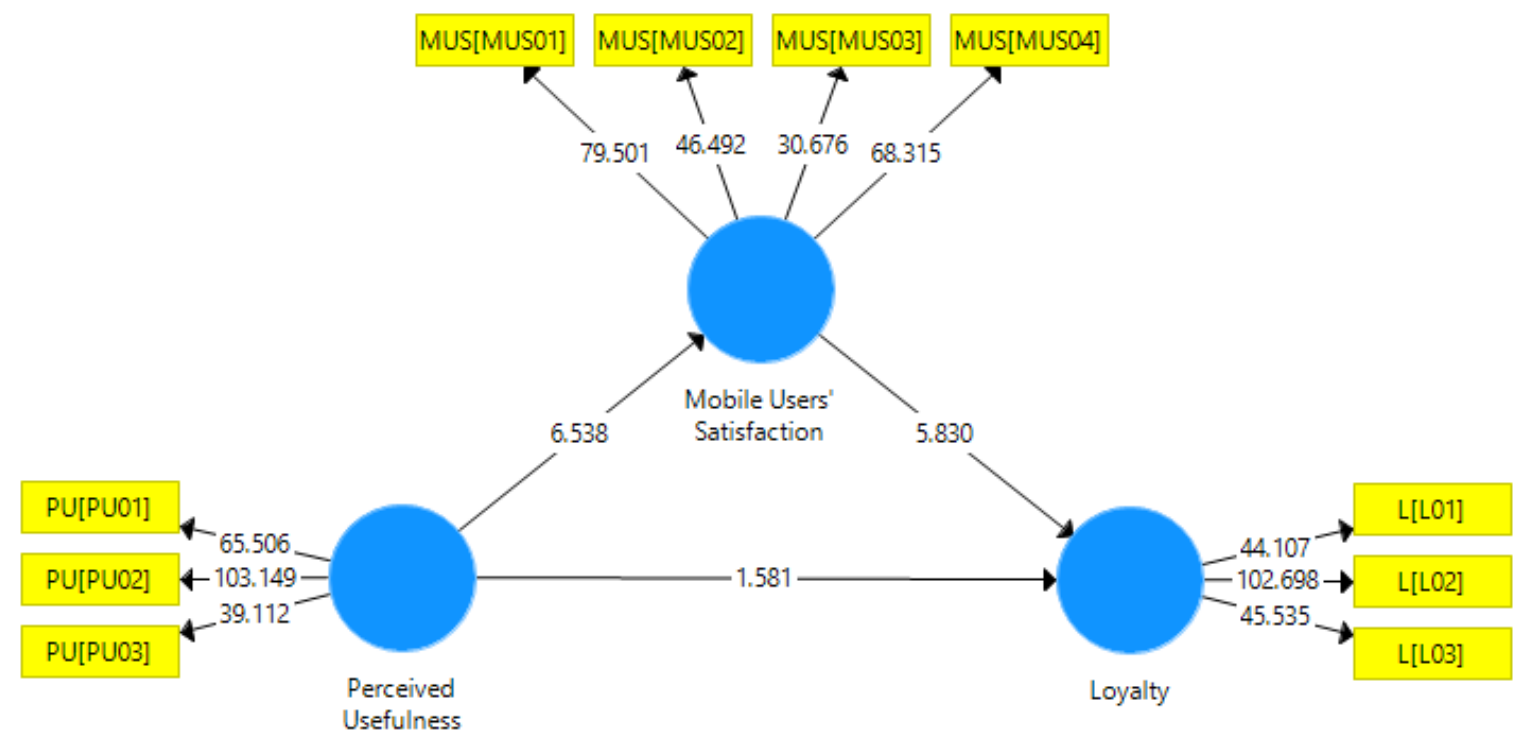

Gambar 1. Path Coefficient Value and P-Value

Tabel 8. Hasil Uji Hipotesis

\begin{tabular}{|c|c|c|c|c|c|}
\hline Inner-variable correlation & $\begin{array}{c}\text { Path } \\
\text { Coefficients }\end{array}$ & $\begin{array}{l}\text { Standard } \\
\text { Deviation }\end{array}$ & $\begin{array}{c}\mathrm{T} \\
\text { Statistics }\end{array}$ & $\begin{array}{c}\mathbf{P} \\
\text { Values }\end{array}$ & Description \\
\hline Direct Effect & & & & & \\
\hline $\begin{array}{l}\text { Perceived Usefulness -> } \\
\text { Loyalty }\end{array}$ & 0.182 & 0.052 & 3.467 & 0.001 & Significant \\
\hline
\end{tabular}




\begin{tabular}{llllll} 
Perceived Usefulness -> & 0.335 & 0.051 & 6.538 & 0.000 & Significant \\
$\begin{array}{l}\text { Mobile Users' Satisfaction } \\
\text { Mobile Users's Satisfaction }\end{array}$ & 0.311 & 0.053 & 5.830 & 0.000 & Significant \\
$\begin{array}{l}\text { - Loyalty } \\
\text { Indirect Effect }\end{array}$ & & & & & \\
$\begin{array}{l}\text { Perceived Usefulness -> } \\
\text { Loyalty }\end{array}$ & 0.181 & 0.053 & 3.457 & 0.000 & Significant \\
\hline
\end{tabular}

Pada uji pengaruh langsung, analisis model struktural (tabel) menunjukkan bahwa perceived usefulness berpengaruh positif dan signifikan terhadap loyalty ( $B=0.182$, p-value $<0.01$ ). Hasil analisis juga menunjukkan bahwa perceived usefulness berpengaruh positif dan signifikan terhadap mobile users' satisfaction ( $B=0.335$, nilai-p $<0,01)$. Selain itu, hasil uji hipotesis terakhir menunjukkan bahwa mobile users' satisfaction berpengaruh positif dan signifikan terhadap loyalty $(B=0.311$, nilai- $p<0,01)$.

Dalam penelitian ini, analisis mediasi juga dilakukan untuk menjelaskan lebih lanjut hubungan antar variabel dalam model konseptual yang diusulkan. Hasil pengujian menunjukkan bahwamobile users' satisfaction secara langsung, positif, dan signifikan dipengaruhi perceived usefulness $(B=0.335$, $p$-value $<0.01$ ) dan secara langsung, positif, dan signifikan mempengaruhi loyalty $(B=0.181$, $p$-value $<0.01$ ). Hal ini menunjukkan mobile users' satifaction memberikan efek mediasi antara perceived usefulness terhadap loyalty (bersifat complementary mediation).

\section{PEMBAHASAN}

Dalam perspektif akademis, hasil penelitian ini memperkuat temuan penelitian sebelumnya dan sekaligus meningkatkan literatur pemasaran di bidang adopsi teknologi dan perilaku konsumen. Peran persepsi kemudahan penggunaan sebagai anteseden kepercayaan dan kegunaan yang dirasakan mendukung hasil studi oleh (Gefen et al., 2003), (Wu dan Chen, 2005) dan (Tung et al., 2008).

Penelitian ini menegaskan pengaruh perceived usefulness terhadap mobile users' satisfaction dan loyalty pada penggunaan layanan aplikasi Go-Jek. Perceived usefulness atau kegunaan yang dirasakan pengguna aplikasi layanan Go-Jek akan membentuk kepuasan yang baik mengenai segala hal yang terdapat pada aplikasi Go-Jek, yang secara positif akan mempengaruhi loyalitas pengguna. Temuan ini sejalan dengan Rania et al (2018) yang menemukan hubungan positif antara perceived usefulness dan loyalitas serta hubungan positif antara kepuasan pengguna dan loyalitas. 
Perceived usefulness berfungsi sebagai determinan yang berpengaruh kuat dalam pembentukan kepuasan pengguna mengenai layanan aplikasi ponsel dan loyalitas pengguna yang dirasa sesuai dengan kepribadian pengguna. Temuan ini secara empiris membuktikan pentingnya perceived usefulness yang dirasakan oleh seseorang menunjukkan bahwa pengguna aplikasi ponsel dapat merasakan seberapa manfaat dan sesuai dirinya dengan karakteristik layanan aplikasi ponsel yang disukainya pada beberapa aspek persepsi yang terbentuk. Perceived usefulness menjadi salah satu kunci untuk membentuk kepuasan, dan loyalitas. Penelitian ini juga menekankan pada penggunaan layanan aplikasi di dalam Go-Jek yang paling diminati atau sering digunakan. Selain itu, penelitian ini juga memberikan hasil seberapa banyak pengguna aplikasi Go-Jek menggunakan layanan dan mengeluarkan dana dalam satu bulan.

\section{SIMPULAN}

Dari hasil pengolahan data survei dan model konseptual yang ada, dapat diketahui bahwa semua hipotesis yang dikemukakan dalam penelitian ini mendukung dan terbukti adanya hubungan positif yang signifikan dalam persamaan struktural masing-masing. Berdasarkan temuan tersebut, dapat disimpulkan beberapa hal sebagai berikut:

1) Perceived usefulness berpengaruh positif dan signifikan terhadap loyalitas, artinya semakin baik perceived usefulness pada aplikasi layanan Go-Jek maka semakin tinggi pula loyalitas penggunanya.

2) Percaived usefulness berpengaruh positif dan signifikan terhadap mobile users' satisfaction, artinya semakin baik perceived usefulness pada aplikasi layanan Go-Jek maka semakin tinggi pula kepuasan penggunanya.

3) Mobile users' satisfaction berpengaruh positif dan signifikan terhadap loyalitas, artinya semakin baik kepuasan pengguna aplikasi layanan Go-Jek, maka semakin tinggi pula loyalitas penggunanya.

\section{KETERBATASAN}

Berdasarkan hasil penelitian yang telah dilakukan, terdapat beberapa keterbatasan yaitu:

1) Penelitian ini hanya meneliti kepuasan dan loyalitas pengguna aplikasi ride-hailling yang mana tidak ada tambahan variabel lain yang lebih kompleks untuk meneliti kondisi kemajuan teknologi

2) Penelitian ini hanya memiliki satu objek penelitian yaitu aplikasi Go-Jek. Tidak terdapat aplikasi kompetitor atau pembanding lain.

\section{REKOMENDASI}


Berdasarkan keterbatasan penelitian maka dapat disarankan atau rekomendasikan penelitian di masa mendatang yaitu:

1) Penelitian di masa mendatang perlu mempertimbangkan untuk menggunakan konstruk lain seperti persepsi nilai yang dapat menjadi prediktor kepuasan pengguna. Selain itu penelitian berikutnya juga bisa menggunakan karakteristik demografi misalnya usia dalam membedakan tingkat penerimaan kemanfaatan dan kemudahan sebuah teknologi baru.

2) Penelitian dimasa mendatang perlu memperkaya temuan studi empiris dengan mengkaji teknologi aplikasi layanan jasa transportasi lainnya maupun jasa dalam kategori yang berbeda.

\section{DAFTAR PUSTAKA}

Akbar, M. M. \& Parvez, N. 2009. Impact of Service Quality, Trust, and Customer Satisfaction on Customer Loyalty. ABAC Journal. 29 (1): 24-28

Amin, et al., (2014), User Satisfaction with Mobile Websites: The impact of Perceived usefulness, Perceived Ease of Use, and Trust, Nankai Business Review International, Vol. 5 No. 3, pp. 258-274.

Barry J Babin; Jean-Charles Chebat; Richard Michon (2004). Perceived appropriateness and its effect on quality, affect and behavior. , 11(5), 0-298.

Calisir, Nese; Basak, Ecem; Calisir, Fethi (2016). Key drivers of passenger loyalty: A case of Frankfurt-Istanbul flights. Journal of Air Transport Management, 53(), 211-217.

DeLone, W. H., \& McLean, E. R. (2016). Information Systems Success Measurement. Foundations and Trends in Information Systems. Hanover, United States: now Publishers Inc.

Elkhani, N., Soltani, S., \& Nazir Ahmad, M. (2014). The effects of transformational leadership and ERP system self-efficacy on ERP system usage. Journal of Enterprise Information Management, 27(6), 759-785.

Fan, J. C., \& Fang, K. (2006). ERP Implementation and Information Systems Success: A Test of DeLone and McLean's Model. In 2006 Technology Management for the Global Future PICMET 2006 Conference (pp. 1272-1278).

Faqih, K. M. S. (2016). An empirical analysis of factors predicting the behavioral intention to adopt Internet shopping technology among non-shoppers in a developing country context: Does gender matter? Journal of Retailing and Consumer Services, 30, 140-164.

Fornell, C., \& Larcker, D. F. (1981). Evaluating Structural Equation Models with Unobservable Variables and Measurement Error. Journal of Marketing Research, 18(1), 39-50.

Fred D. Davis (1989). Perceived Usefulness, Perceived Ease of Use, and User Acceptance of Information Technology. MIS Quarterly, 13(3), 319-340.

Hair, J., Hult, G. T. M., Ringle, C. M., \& Sarstedt, M. (2013). A Primer on Partial Least Squares Structural Equation Modeling (1st Edition). SAGE Publications, Inc. 
Hsin-Hui Lin; Yi-Shun Wang (2006). An examination of the determinants of customer loyalty in mobile commerce contexts. , 43(3), 271-282.

Joo, J., \& Sang, Y. (2013). Exploring Koreans' smartphone usage: An integrated model of the technology acceptance model and uses and gratifications theory. Computers in Human Behavior, 29(6), 2512-2518.

Lo, May-Chiun; Ramayah, T.; Min, Hii Wei; Songan, Peter (2014). The relationship between leadership styles and organizational commitment in Malaysia: role of leader-member exchange. Asia Pacific Business Review, 16(1-2), 79-103.

Mai, R., Hoffmann, S., Schwarz, U., Niemand, T., \& Seidel, J. (2014). The shifting range of optimal web site complexity. Journal of Interactive Marketing, 28, 101-116.

Miyoung Jeong; Carolyn U. Lambert (2001). Adaptation of an information quality framework to measure customers' behavioral intentions to use lodging Web sites. , 20(2), 0-146.

Mokhtar, S. A., Katan, H., \& Hidayat-ur-Rehman, I. (2018). Instructors' behavioural intention to use Learning Management system: An integrated TAM perspective. TEM Journal, 7(3), 513-525.

Parasuraman, A. (2005). E-S-QUAL: A Multiple-Item Scale for Assessing Electronic Service Quality. Journal of Service Research, 7(3), 213-233.

Santhika, E. (2018). GoPay Masalah, Pengguna Gojek Disarankan Bayar Tunai https://cnnindonesia.com/teknologi/20180511163142-185-297475/gopaymasalah-penggunagojek-disarankan-bayar-tunai.

Sari, M. A., Listiawati, R., Novitasari, N., \& Vidyasari, R. (2019). Analisa pengaruh daya tarik promosi, persepsi kemudahan, persepsi manfaat, persepsi keamanan terhadap minat penggunaan e-wallet (Studi kasus produk gopay dan link aja pada masyarakat pengguna di wilayah Jabodetabek). Jurnal Ekonomi \& Bisnis, 18, 126- 134.

Shamah, Rania A.M.; Mason, Michela C.; Moretti, Andrea; Raggiotto, Francesco, (2018). Investigating the antecedents of African fast food customers loyalty: A self-congruity perspective. Journal of Business Research, 86(),446-456.

Singh, N., \& Sinha, N. (2020). How perceived trust mediates merchant's intention to use a mobile wallet technology. Journal of Retailing and Consumer Services, 52.

Singh, N., Sinha, N., \& Liébana-Cabanillas, F. J. (2020). Determining factors in the adoption and recommendation of mobile wallet services in India: Analysis of the effect of innovativeness, stress to use and social influence. International Journal of Information Management, 50, 191205.

Türkyılmaz, Ali; Özkan, Coşkun (2007). Development of a customer satisfaction index model. Industrial Management \& Data Systems, 107(5), 672-687.

Thirumalaisamy P; Song, Le Huu (2020). Predominant secondary dengue infection among Vietnamese adults mostly without warning signs and severe disease. International Journal of Infectious Diseases, (), S120197122030713X-.

Wang, Hsiu-Yu; Liao, Chechen; Yang, Ling-Hui (2013). What Affects Mobile Application Use? The Roles of Consumption Values. International Journal of Marketing Studies, 5(2), -.

Yang, S., Lu, Y., Gupta, S., Cao, Y., \& Zhang, R. (2012). Mobile payment services adoption across time: An empirical study of the effects of behavioral beliefs, social influences, and personal traits. Computers in Human Behavior, 28(1), 129-142. 
Yeo, B. L., Mohamed, R. H. N., \& Muda, M. (2016). A study of Malaysian customers purchase motivation of halal cosmetics retail products: Examining theory of consumption value and customer satisfaction. Procedia Economics and Finance, 37, 176-182.

Yoo, J., \& Park, M. (2016). The effects of e-mass customization on consumer perceived value, satisfaction, and loyalty toward luxury brands. Journal of Business Research, 69(12), 57755784.

Yuan, S., Liu, L., Su, B., \& Zhang, H. (2020). Determining the antecedents of mobile payment loyalty: Cognitive and affective perspectives. Electronic Commerce Research and Applications.

Zeithaml, V. A. (1988). Consumer perceptions of price, quality, and value: A means-end model and synthesis of evidence. Journal of Marketing, 52(3), 2-22. 